Vol. 5, n`2 | 2001

Varia

\title{
Explaining Long Term Trends in Violent Crime
}

Helmut Thome

\section{(2) OpenEdition \\ Journals}

Electronic version

URL: https://journals.openedition.org/chs/738

DOI: $10.4000 /$ chs.738

ISSN: 1663-4837

\section{Publisher}

Librairie Droz

Printed version

Date of publication: 1 January 2001

Number of pages: $69-86$

ISBN: 2-600-00664-8

ISSN: $1422-0857$

Electronic reference

Helmut Thome, "Explaining Long Term Trends in Violent Crime", Crime, Histoire \& Sociétés / Crime, History \& Societies [Online], Vol. 5, n² | 2001, Online since 02 April 2009, connection on 23 March 2022. URL: http://journals.openedition.org/chs/738 ; DOI: https://doi.org/10.4000/chs.738

(c) Droz 


\title{
Explaining Long Term Trends in Violent Crime
}

\author{
Helmut Thome'
}

\begin{abstract}
Gurr and others have demonstrated that the long-term development of homicide rates in Europe follows a $U$-shaped curve: There is a fairly steady (though non-linear) decline since the 17th century (or even earlier, in some regions) till the middle of the 20th century, and a fairly steady increase since the 1960s. It is tentatively assumed in this article that the increase in the second half of the 20th century does not indicate a temporary deviation from the long-term trend but rather a trend reversal. Thus, a theory propounded to explain aggregated homicide rates must account for the secular decline and for the presumed increase as well. It is argued in this paper that Elias's theory of the processes of civilization and Durkheim's theory on social differentiation and moral development offer a good starting point for constructing such a theoretical account. Based on an analysis of German crime data (1898-1902) some empirical evidence is presented to support Durkheim's hypothesis that the decline of violence follows from the erosion of "collectivism».
\end{abstract}

Gurr et d'autres auteurs ont démontré que le développement des taux d'homicides sur le long terme suit une courbe en $U$ : on constate un déclin assez constant (quoique non linéaire) depuis le XVII siècle (ou même plus tôt, dans certaines régions), et ce jusqu'au milieu du XX siècle, puis une baisse assez constante depuis les années 1960. On admettra, provisoirement, dans cet article que la baisse de la deuxième moitié du XX $X^{e}$ siècle ne constitue pas une déviation par rapport à la tendance à long terme, mais un renversement de celle-ci. Par conséquent, une théorie visant à expliquer les taux agrégés d'homicides doit rendre compte aussi bien de la baisse séculaire que la baisse présumée. Dans cet article, on avancera que la thèse du processus de civilisation d'Elias et celle de la division du travail social de Durkheim constituent de bons points de départ d'une telle théorie. En se basant sur les statistiques criminelles allemandes (1988-1902), on présente quelques données à l'appui la thèse durkheimienne selon le déclin de la violence découle de l'érosion des solidarités collectives.

1 Helmut Thome is a professor of sociology at the University of Halle (Germany). His interests focus on research methods, long term development of crime, and solidarity structures. Among his articles published in English are: «Dubious cycles: a methodological critique of the Namenwirth/Weber thesis on cultural change with an introduction into filter design methods », Quality \& Quantity 1996, 30, pp. 427-448; «Party mandate theory and time-series analysis: a methodological comment, Electoral Studies, 1999,18 , pp. 569-585; «Solidarity: theoretical perspectives for empirical research", in Bayertz, K., (Ed.), Solidarity, London, Kluwer, 1999, pp. 101-131. He is presently completing a book on time-series analysis and preparing a study on cross-national variation of violent crime. 


\section{INTRODUCTION}

Since Gurr's seminal article ${ }^{2}$, the long term development of violent crime or,

$\checkmark$ more specifically, homicide rates in Europe since the early modern age up to the (near) present has been depicted as a «U-shaped curve»: a non-linear but fairly steady decline over several centuries followed by an upward movement in the second half of the 20th century. Manuel Eisner has recently extended Gurr's work considerably by adding pertinent information derived from a series of studies carried out by various researchers who provided frequency counts of murder and manslaughter from various European regions in different time periods ${ }^{3}$. Eisner's data set includes some 290 single point estimates for the pre-statistical period. Thus, we now have a much better data base renderring the idiosyncracies of each study less influential in shaping the overall trend pattern. The $U$-shaped curve of the transsecular trend, however, has been confirmed. Gurr himself and several other historians of crime have interpreted the increase of homicide since, roughly, the 1960s as just one of several deviations around the persistently downward slanting trend, caused by local circumstances and short-lived forces. The task for the theoretician has been defined accordingly: explaining the secular decline of violent crime and short-term departures from it. In the present paper, however, I tentatively assume that the upward movement in the second half of the 20th century has initiated a long term reversal of the previous trend: higher and presumably still rising levels of violent crime will be with us for quite a while. This implies a redefinition of the explanandum. We have to search for theories that are able to explain both, the secular decline since the 17th century (or even earlier) and the (presumably) longterm increase since the 1960 s. We cannot content ourselves with a theory that explains the one and not the other. Historians of crime and criminal justice seeking an explanation for the downward trend have, above all, turned to Norbert Elias and his account of the «civilizing process ${ }^{4}$. As will be argued in the next section of the present paper, Elias's theory can also help to understand the trend reversal. Additional insights can be gained from another sociological classic, Émile Durkheim, as will be shown in the third section.

\section{THE CIVILIZING PROCESS AND THE DEVELOPMENT OF VIOLENT CRIME}

When in the mid-1930s Elias wrote his (now) famous book Ueber den Prozeß der Zivilisation including an "outline» of a theory of the "civilizing process» he did not intend to explain the long-term development of violent crime. But when his almost forgotten book finally gained world wide recognition in the 1970s, historians of crime and criminal justice became particularly impressed. As Johnson \&

2 Gurr (1981), cf. Gurr (1989).

3 Eisner $(1995 ; 2001)$.

4 Cf. Elias (1982). As Johnson and Monkkonen (1996, p. 4) note: «One of the most notable effects of the recent work on the history of crime... has been to force historians to reassess (or assess for the first time) the work of the sociologist Norbert Elias. Without a doubt, his work has gained the greatest respect of any single theoretician». 
Monkkonen note: «Elias's significance has come to be recognized in part because his descriptions of the 'civilizing process' match so well what crime historians have been finding $»^{5}$. Elias has been particularly impressive in demonstrating the dynamic interplay between various components of social structure, culture, and personality in the transition from feudal to modern societies in Europe. According to Elias, the major pacifying forces that have been unfolding in the long extended civilizing process (or processes) are the following:

(1) The creation of the state monopoly of violence and its subsequent legitimation in the processes of democratization the second stage has often been neglected, and we even have to add a third stage, as I will argue later) ${ }^{6}$.

(2) The extension of the market economy implying the elongation of action chains and increasing functional interdependencies between individual and collective actors.

(3) The promulgation of a culture of non-violence, increasing condemnation of and even revulsion at the infliction of serious bodily harm including corporal punishment.

(4) The transformation of personality structures in the direction of increased selfcontrol.

All of these processes Elias has shown to be closely interrelated in a way that cannot be delineated in this paper. They are more or less cumulative and sufficiently continuous $^{7}$ as to fit into a trend pattern that can be imagined to be inversely related to the secular decline of homicide rates. If used as an explanatory account for violent crime, the weakest element in this scheme, it seems to me, is the notion of affect control. Even if one assumes that the capacity of individual persons to control their aggressive impulses has increased and trickled down, so to speak, from higher to lower social strata (an assumption not shared by a number of cultural historians), this does not necessarily imply less killings. As Pieter Spierenburg has pointed out: «If increasing affect control, the taming of spontaneous drives and impulses, is indeed the dominant sociopsychological trend over the last seven centuries or so of European history, a high incidence of deliberate killings today would not be incompatible with it... (T)he proportion of 'killings in affect',(...), may have declined, while that of carefully premeditated murders may have remained stable or even risen ${ }^{8}$. There is also a severe conceptual problem involved in Elias's notion of affect control. When he explains why the disciplinary forces located in the developing state authorities and market institutions should have stimulated the formation or

5 Johnson, Monkkonen (1996, p. 4).

6 The state's monopoly of violence, of course, does not rule out the possibility that the "state» wages war against other states or against parts of its own populace. Criminal actions by the state (an important subject in itself) are not considered in this paper.

7 This statement about the cumulative unfolding of a pattern is meant to be descriptive, I do not wish to subscribe to the evolutionary logic adopted by Elias. Although certain configurations may display the potential of systemic unfolding, the unfolding is unlikely to proceed in in a linear way. At its beginning, it is also unclear whether or not it leads to a state of equilibrium, dissolution, smooth transformation or violent transition to yet another configuration. 
strengthening of internalized control patterns, Elias, at least in his original study, points to force («Zwang») and fear («Angst») as the prime mediators ${ }^{9}$. So he expressly claims that the adolescent youth will never advance to a sufficient regulation of his behavior without experiencing «fear, arising from other human beings ${ }^{10}$. Now, force and fear may produce strong super-egos, but weak egos; they promote rigidly controlled behavior, but may also become the seedbed of suppressed neurotic energies waiting for an occasion to explode; they are likely to create authoritarian characters that may refrain from individual acts of crime but quickly unleash their suppressed emotions and turn to violence, if the state or another figure of authority legitimates or demands such action. The rise of totalitarian regimes in the 20th century, particularly nazism in Germany, and, on a diffferent scale, the destructive consequences of sexual repression point to the limits of an internalized control pattern that has been implanted by force and fear ${ }^{11}$. Elias' theory of affect control therefore needs to be contrasted with another model of acquiring «moral competence» and flexible behavioral control, a model originating in the works of Piaget ${ }^{12}$ and G. H. Mead: The learning of moral standards and the creation of a reflective self through participation in cooperative transactions between «equals »; the internalization of the control pattern of "dialogue» which is supported, in the political sphere, by public discourse and democratic institutions.

Despite these shortcomings, the first three of Elias's generalizations mentioned above, may still be seen as foundational to any attempt to explain the long downward trend in homicide committals since the 17th century. But what about the manifold digressions from this trend, in particular the fairly steady increase in violent crime in the second half of the 20th century ? There is a strong evolutionary component in Elias's theory, but he has always allowed for perturbances, temporary stops or turns, even phases of decivilization. There are problems of logical coherence involved in that, and there is a strong temptation to settle down with flimsy ad hoc explanations. But one path that one might follow, is traced out in Elias's reflections upon the shifting balance between the «I» and the «We», the weight and significance accorded, respectively, to the «individual » and the «collective» components that are to be integrated within personal identities, a task on which one might succeed or fail - more or less ${ }^{13}$. Underlying these considerations is the idea that various components of civilizing processes might move at different speeds, one

For a concise critique of this conception see Honneth, Joas (1980, pp. 115-123).

10 Elias (1980, vol. 1, p. 447).

11 Spierenburg refers to a rising or continuously high level of homicides within the biological family. He then offers the following interpretation: "If family homicide maintains a relatively stable level even today, this would be compatible with the theory of an increase in affect regulation. As affects and emotions were the subject of increasing constraints in the wider society, the nuclear family came to serve as an island where emotions were cultivated» (1996, pp. 71-72). Pushed to its logical end the argument may read: The family had to pay the psychological costs of the suppression of emotions outside its bounds. Later in his work Elias has introduced the concept of «deformalization» intended to better account for the growing need of having more flexible structures of self-control. This new analytical element, however, has simply been added to rather than integrated with the old concept.

12 Piaget's critique (published in 1932) of Durkheim's ideas on moral education (stressing the role of hierarchy and disciplin) would be even more pertinent with respect to Elias's conception.

13 Cf. Elias (1991, pp. 209-315). 
running ahead of the other that might catch up later (or, perhaps, not at all). For the more recent period, Elias has pointed to the changing role of the nation-state which has been losing its position as the highest-ranking «survival unit» while personal identities are still attached to it. This incurs strain and stress experiences which might easily be related to the concept of «anomie» as introduced by Durkheim. Elias seems to assume that reintegration on a supra-national, possibly world wide, basis would eventually be achieved. If we accept this evolutionary perspective, we are led to assume the recent increase of violent crime is a temporary occurrence. At present, however, I do not see any strong indicators that would support the hypothesis that a world monopoly of power might be achieved in the foreseeable future. But if we discard the evolutionary component in Elias's theory, we may still use the more specific hypotheses to explain the presumed trend reversal. If, for example, the development of the state's monopoly of violence and its subsequent «domestication» within liberal democratic systems is chiefly responsible for decreasing interpersonal violence, one should expect an increase of such violence, if the legitimate monopoly of violence is weakened or crumbling without being supplanted by functionally equivalent forces. Several researchers have developed strong arguments and presented a number of indicators that lend credence to the hypothesis that the institutional nexus in which the legitimacy and the effectiveness of the state monopoly of violence were closely intertwined with each other has started to erode and will continue to do so. The German sociologist Trutz von Trotha speaks of a «oligarchic-preventive order of security $\gg$ (OPOS) which has been emerging in Western democracies during the last decades ${ }^{14}$. It is characterized, among other things, by the remarkable growth of private security industries and services; moves towards privatization of prisons; the promulgation of communitarian control-orders; the 'mechanization' of policing. He notes that the newly emerging OPOS is without a «center», that the responsibilities of the political and administrative power centers have been replaced by the purchasing power of clients in security markets which transform the structures of economic inequality into the social inequality of differentially available security. This commodification of security normalizes the use of violence which progressively penetrates into the web of social relationships ${ }^{15}$. The validity of v. Trotha's analysis cannot be discussed in this article, but note that the theses about a general «legitimation crisis $»^{16}$ and the dissolution of the functional prerogatives of the state ${ }^{17}$ have been with us for quite a while. In a recent book, Gary LaFree has linked the rising crime rates in the United States since the 1960s to a wide variety of indicators of diminished legitimacy of social, political, and economic institutions ${ }^{18}$. The protest movements that called into question the legitimacy of «the system " in the 1960 s were primarily politically and morally motivated (e. g., civil rights issues and the war in Vietnam in the USA, the insistence of the young generation to discuss responsibilities for the nazi-terror in Germany). A second, more powerful and still unfolding wave of delegitimation and diminishing state power has been set in motion by various technological innovations and economic

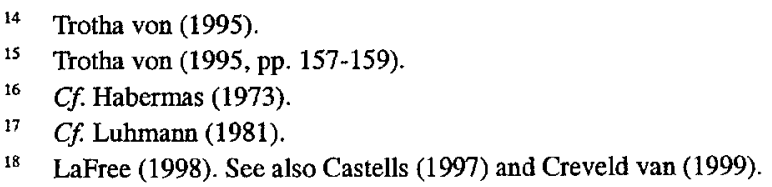


developments now summarized under the heading of «globalization». In these processes a positive feedback system seems to have established itself in which diminishing control capacities of the nation-state undermine its legitimacy and subsequently further diminish its regulatory powers ${ }^{19}$. In particular, globalizing free market economies have undermined the state's monopoly of taxation, upon which to recall Elias - the monopoly of violence had been founded. On a more concrete level of analysis one would have to talk about the internationalization of organized crime, and about technological developments in weaponry and worldwide electronic communication that have put certain types of criminals into a rather advantageous position over against the state. As a consequence, the state increasingly finds itself in a dilemma whereby it either has to let go or apply «big brother» strategies outside the legitimation boundaries.

A second line of reasoning may elaborate upon Elias's somewhat deficient conception of affect control and refine it into a multi-dimensional concept of selfcontrol, as suggested, fo example, by Gottfredson \& Hirschi ${ }^{20}$. Eisner, drawing upon this improved concept, has advanced the hypothesis that in (post-)modern societies there is opening up a growing gap between the increasing demand for self control ${ }^{21}$ and the diminishing ability of the individual person to acquire and supply self control. This hypothesis is compatible with Elias's theory and may even draw on it. Elias, remember, had linked the strengthening of self-control to the preponderance of long action chains rewarding those people that were able to delay satisfaction and plan their actions far ahead. This «long view» has become less functional in postmodern «risk» societies (Beck), where future outcomes of personal investments have become rather unpredictable. Also, the protection of the «private sphere», a structural pre-requisite for developing strong self-control, seems to be crumbling, not by the intrusion of the state, perhaps, but by the transgressions of the mass media and business communications. These hypotheses would need more elaboration, of course, but at this point they are only intended to indicate how Elias's theoretical framework might be used to account not merely for the long downward trend in homicide but also to generate hypotheses aimed at explaining the presumed trend reversal.

\section{DURKHEIMIAN PERSPECTIVES}

\subsection{Collectivism versus Individualism}

Additional insights are provided by another sociological classic, Émile Durkheim, who has been largely neglected or oddly misinterpreted by historians of crime $^{22}$. He has been branded as a conservative thinker sticking to collectivist ideol-

19 Cf. Castells (1997).

20 Gottfredson, Hirschi (1990).

21 Eisner $(1995 ;$ 1997). Maybe this demand for self-control is not so much growing but becoming increasingly contradictory asking for highly self-disciplined behavior in the sphere of "production" and unfettered indulgence in the sphere of «consumption» ( $c f$. Bell's thesis on the «cultural contradictions of capitalism», 1976).

22 Charles Tilly's verdict about the «Useless Durkheim» (Tilly 1981) is utterly mistaken. 
ogy. The opposite is true. Some 40 years before Elias wrote his book, Durkheim suggested «that with the progress of civilization homicide decreases $»$. The reason for this, he saw in the de-mystification of the collectivity and its devaluation relative to the «worshipping » of the individual. «Collectivism» he construed as an integrative pattern in which the group - the family, the clan, the caste, a religious community, the nation - was valued more, much more, than the individual and his well-being. This pattern had to break down in the course of increased social differentiation ${ }^{24}$. In collectivist societies the individual is enmeshed in a tightly woven web of symbolic references and intimations that easily arouse passions directed against those who fail to pay due respect to the norms and the honor of the group on which the honor of the individual member is dependent. He himself and his life count little. The collectivity takes on the quality of a sacred being demanding harsh reactions against those who step out of line, thereby creating a culture of violence. High levels of passion and low respect for the individual person render the individual more likely to physically attack another person. Although Durkheim notes in a very general way that «passion leads to violence» 25 , he does not construe the problem in terms of innerpsychic control mechanisms. Rather, the passions are viewed as being directly regulated or molded by culture. The reason why passions are lower or more constrained in individualist cultures (though the collective sentiment may value the individual just as intensely as the group before) seems to be that the person who violates the norms (and is to be punished for that) is, so to speak, an incarnation of the very object which is now being worshipped, namely, the individual in general ${ }^{26}$. Thus, there is a shift in perspective: pacification is not effected by disciplinary forces holding down individual impulses but by freeing the individual from closely knit bondages that kept him tied into the collectivity. Durkheim believes, however, that it is not so much the rise of individualism that directly causes the reduction of homicide committals but rather the erosion of collectivism (Durkheim 1992, 115). He has been lead to this conclusion mainly by empirical observations. He notes (from the data that were available to him) that while the homicide rate had been decreasing, assault and theft (that also count as offenses against the individual person) had been rising at the same time. I think that we can dismiss this argument on methodological grounds: (1) As Gurr has pointed out ${ }^{27}$, in the 19th century the increase in assault rates may be due to a growing sensitization towards even minor forms of inflicting bodily harm, which in turn stimulated reporting and prosecution. (2) If the upward trend had been real, this would still not disprove the notion that individualist orientations contribute to lowering any forms of violent behavior. It could just be that, temporarily, other forces and motives conducive to violence had become stronger (like economic hardship, political conflict, or a rapid acceleration of social change).

23

«(T)hose causes put together which, by increasing diversities of the members of all societies, have left them with no essential characteristics in common except those they get from their intrinsic quality of human nature. It is this quality that quite naturally becomes the supreme object of collective seusibility» (Durkheim 1992, p. 112). So, individualism is intrinsically related to universalism.

26 Cf. Durkheim (1978).

27 Gurr (1989). 


\subsection{Some empirical evidence}

Durkheim's hypothesis about the relationship between collectivism/individualism and murder has been confirmed by several cross-national studies ${ }^{28}$ using individual level or aggregated data. I can now present additional evidence based on German data available for more than 800 districts (Land-and Stadtkreise) of the German Reich. Conviction rates for assault and battery (serious bodily harm) have been calculated per 100000 legally liable persons more than 17 years old. The rates were averaged over five years from 1898 to 1902. For most of these districts the birth rates (number of births per 1000 inhabitants) are also available, averaged over the years 1899 to 1901. I propose to interprete the birthrate as a correlational (not an analytical) indicator of the relative degree of collectivist versus individualist orientation in a given district ${ }^{29}$. The higher the birthrate, the stronger the degree of collectivist and the weaker the individualist orientation. Figure 1 presents the scatterplot and the regression line relating assault and battery $(A B)$ to the birthrates of ca. 800 German districts.

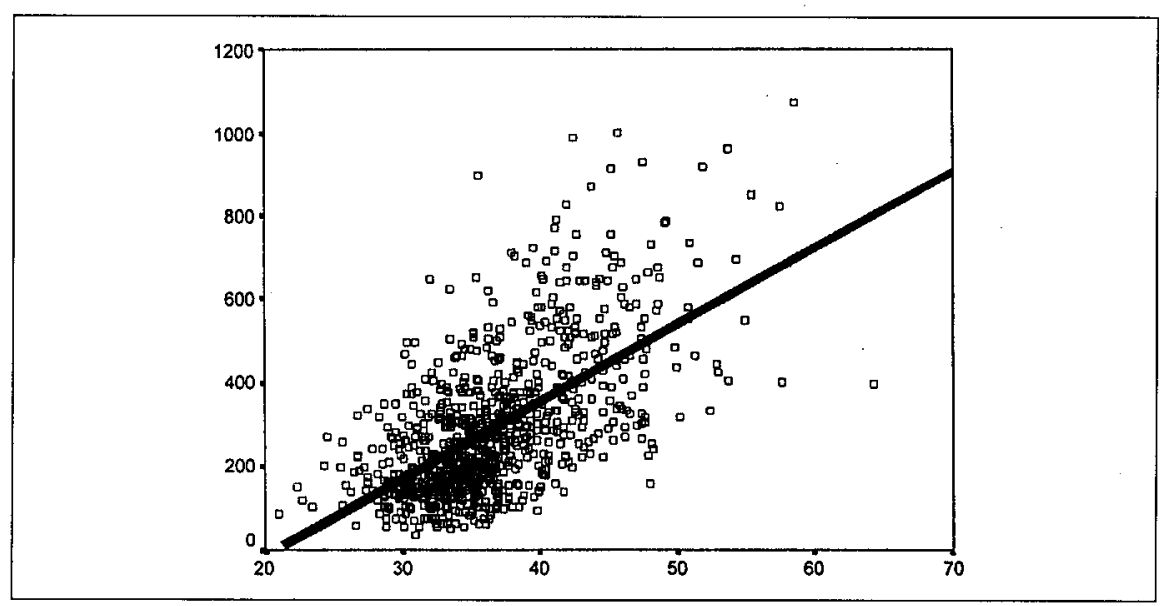

Figure 1: Assault and Battery (per 100000 legally liable persons) depending upon birthrate (per 1000 inhabitants). (R-Squ. $=0.37$ )

The scatterplot demonstrates that 37 percent of the variation in $A B$ can be explainted by birthrate. If we perform the same regression analysis for the somewhat less heterogenous Prussian districts (more than 500 cases), the percentage of explained variance increases to as much as 50 percent. For the Prussian districts we can add a number of structural variables in order to construct a simple path model with birthrate as the intervening variable. The regression results are presented in Figure 2.

28 See, for example, Karstedt (2001), Messner (1982).

${ }^{29}$ I would not interprete the birthrates of contemporary societies in such a way. 


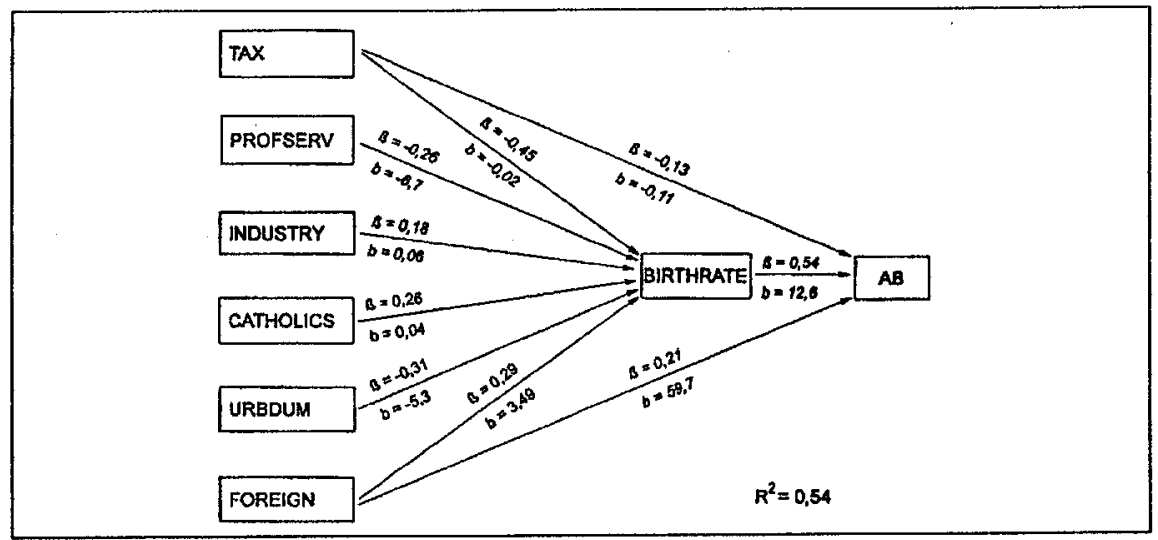

Figure 2: Pathmodel relating exogenous variables and birthrate to assault and battery (Prussian districts)

The structural variables are: the proportion of people who had enough income or other fortunes to pay a specific tax, Ergänzungsabgabe (TAX); the proportion of the labor force employed in industry (INDUSTRY); the proportion of the labor force working in public services or as professionals (PROFSERV); the proportion of catholics (CATHOLICS); a dummy-variable that differentiates between urban and rural districts (URBDUM); and a dummy-variable identifying those districts which were inhabited by a high proportion of people from Poland or the Baltic countries (FOREIGN). All these variables add only $4 \%$ to the amount of variance explained by birthrate alone. If on the other hand, we control for all these structural properties, the birthrate remains the most effective predictor with a standardized regression coefficient of $\beta=0.54$. The only other variables that remain statistically «significant», if we control for birthrate, are the indicator for relative economic prosperity $(\beta=-0.13)$ and the indicator for ethnic conflict $(\beta=0.21)$. But they explain assault and battery to a much lesser extent than the birthrate. This result was not anticipated, I must admit. Thus, I offer a post festum explanation, but I can only offer it in terms of Durkheimian theory: The result makes sense if we accept the birthrate as a cultural indicator for the relative weight of collectivist versus individualist orientation present in a given district. They are connected in a number of ways that cannot be discussed here at length. For example, at the end of the 19th century outside the agrarian sector large numbers of children generally were no longer an economic «asset», the two-generation «nuclear» family was becoming predominant, emotional attachment between the spouses (derived from the partners's individual characteristics) and between parents and children were gaining more importance. In general, the individual (child) «counts» more, receives more attention and material rewards or investments, and develops a clearer conception of his own personal value as a human being, if the number of « equals» (siblings) around him is small rather than large ${ }^{30}$. So, my inter-

30 The relationship probably is non-linear: the positive effects tend to be reversed, if there are not enough equals available for reciprocal exchanges. The one-child family, however, was still rare at the end of the 19th century. 
pretation of birthrates can be defended in a three-step argument: First, those structural forces (like urbanization and economic development) that made for lower birthrates also promoted increased individualization (thus producing a concomitant viz. correlational relationship between the two). Second, lower birthrates themselves take on causal significance: families with less children offer better opportunities (to parents as well as to their children) for individuation. Third, even after «holding constant» major structural variables and religious composition ( $c f$. figure 2) birthrates uniquely account for 20 percent of the rather large variation in $A B$-rates that range from 34 to 1074 convictions per 100000 legally liable adults ${ }^{31}$. I simply do not see any alternative hypothesis (different from the Durkheimian interpretation) that would do a better job in explaining these crime rates ${ }^{32}$.

It is certainly true (as one of the reviewers has critically remarked) that «a high birthrate... can be an indicator of a number of things». A positive hypothesis, however, should not be rejected before an alternative hypothesis has become available. I have examined two alternatives that one might think of. One might suspect, for example, that the birthrate confounds cultural patterns with demographic and other social characteristics like age and the sex-ratio. For some 35 large cities we can control for the sex-ratio given in the cohort of 25 to 34 year olds. The correlation between birthrate and crime rate, however, is hardly affected, Pearson's $r$ only drops from 0.69 (bivariate correlation) to 0.61 (partial correlation). One might also, secondly, consider the possibility that birthrates mainly reflect class composition, since the impoverished industrial proletariat (unskilled workers) had higher birthrates and, presumably, higher rates of violent crime than the middle classes, particularly in the cities. If this had been the case, the correlation between birthrates and $A B$-rates should substantially decrease once INDUSTRY is held constant. But this is not what happens. The correlation remains on a high level in our sample of big cities, even if the proportion of young males is added as another control variable. I have run some additional analyses with other controls, but the basic result has been maintained ${ }^{33}$.

Another objection that was brought out by one of the reviewers refers to the famous «ecological fallacy» problem. This problem may arise if the theory is expounded on the level of individuals, but the empirical analysis is restricted to using aggregated data. In Figure 2 we have seen, for example, that there is a positive correlation between the proportion of Polish people living in certain German dis-

31 Different practices of law enforcement, statistical recording and other factors contributing to the "production" of crime rates may have had a large share among the manifold idiosyncratic influences that must have caused this huge variation. Unfortunately, I do not have the data to explicitly control for these factors. On the other hand, there is no reason to assume that they are strongly and systematically related to birthrate in ways remaining uncontrolled by the exogenous variables included in the model.

32 Interpreting decreasing birthrates as a cultural phenomenon is not entirely new, of course. Almost 100 years ago, after a close examination of a number of alternative explanations, the famous German statistician and demographer Georg von Mayr arrived at the conclusion that the change in reproductive behavior resulted from a «conscious suppression of natural fertility « (bewußte Hemmung natürlicher Vermehrung), which he thought was utterly deplorable, a kind of «social suicide " (Mayr von 1917, pp. 116-126). His colleague, Friedrich Prinzig, explicitly argued that «purely egoistic reasons « were a major cause for limiting the number of children (Prinzig, 1901, p. 36).

33 The foregoing is just a small excerpt of a more comprehensive study. A fuller report of it is given in Thome (1999; 2002). The project was supported by a grant (TH 260/3-1) from the Deutsche Forschungsgemeinschaft. 
tricts and the rate of violent crime registered there. This does not imply, however, that Poles are more likely to commit acts of criminal violence than non-Polish people. It might well be that the others (Germans in this case) turned more hostile where the Poles became more numerous. But a theory of ethnic conflict does not need to assume that either the majority (or ruling group) or the minority (or suppressed group) would be more hostile than the other. As long as it only assumes that hostility (violence) rises (perhaps on both sides) if the group discriminated against grows bigger in numbers, the ecological fallacy problem does not arise at all: the level of theorizing concurs with the level of data analysis. Matters are more complicated when we talk about elements of culture and individual attitudes. Though they are conceptually distinct from each other ${ }^{34}$, the assumption is that there is a close correspondence between the cultural and the «average» individual orientation. If «collectivism» (as a cultural pattern indicated by birthrates) is supposed to foster violence, one also assumes that on the attitudinal level the «collectivist» is more inclined to commit acts of criminal violence than the «individualist» (holding other things constant). A positive correlation between the degree of collectivism (birthrate) and the rate of criminal violence, however, does not, on purely logical grounds, preclude the possibility that the «individualists» become more crimeprone than the «collectivists» as the proportion of collectivists increases. I am not aware of any theory that would indeed make such a prediction for the end of the 19th century ${ }^{35}$. So, again, lacking a more convincing alternative it is legitimate to maintain the established (Durkheimian) theory which, after all, is consistent with the empirical observation. One might try to construe a counter-argument along the line that individualists might develop hostile feelings and turn to violent reactions against a disliked and predominant collectivist culture, but I see no sound empirical or theoretical foundation for such a hypothesis. If it were correct, the Durkheimian theory would need some modification and refinement, but even then, its basic proposition that «collectivism» promotes violence (including violent crime) would still be maintained.

\subsection{Moral versus Egoistic Individualism, and Anomie}

The erosion of collectivism, according to Durkheim, has paved the road towards a culture of non-violence ${ }^{36}$. But individualism is not a unitary, homogenous social type. It may degenerate into forms that are conducive to violence, albeit on a lower level. The «healthy» or «normal» type of individualism he calls moral individualism. «Pathological» individualism is referred to as egoistic or excessive individualism. The latter term alludes to a quantitative dimension involved here. Moral individualism, however, cannot simply be placed half-way between collectivism and excessive individualism, because all types of individualism differ from collectivism by valueing the individual more than the group. Collectivism and individualism are types of integration/differentiation. Durkheim adds another analytical dimension, regulation, on which he locates further pathologies: anomie refers to a

\footnotetext{
34 I have discussed these matters at some length in Thome (1981, pp. 54-76).

35 Later on, I will argue that in the second half of the 20th century, in a different structural setting, «excessive» individualism does promote interpersonal violence.

36 Durkheim, too, speaks of societies being more or less civilized.
} 
lack of regulation, fatalism refers to over-regulation ${ }^{37}$. In the case of over-regulation, norms are too restrictive given the degree of social differentiation (and therewith type of integration) that has been reached; they are not accepted (legitimized) by the individuals. Figure 3 tries to represent this analytical scheme.

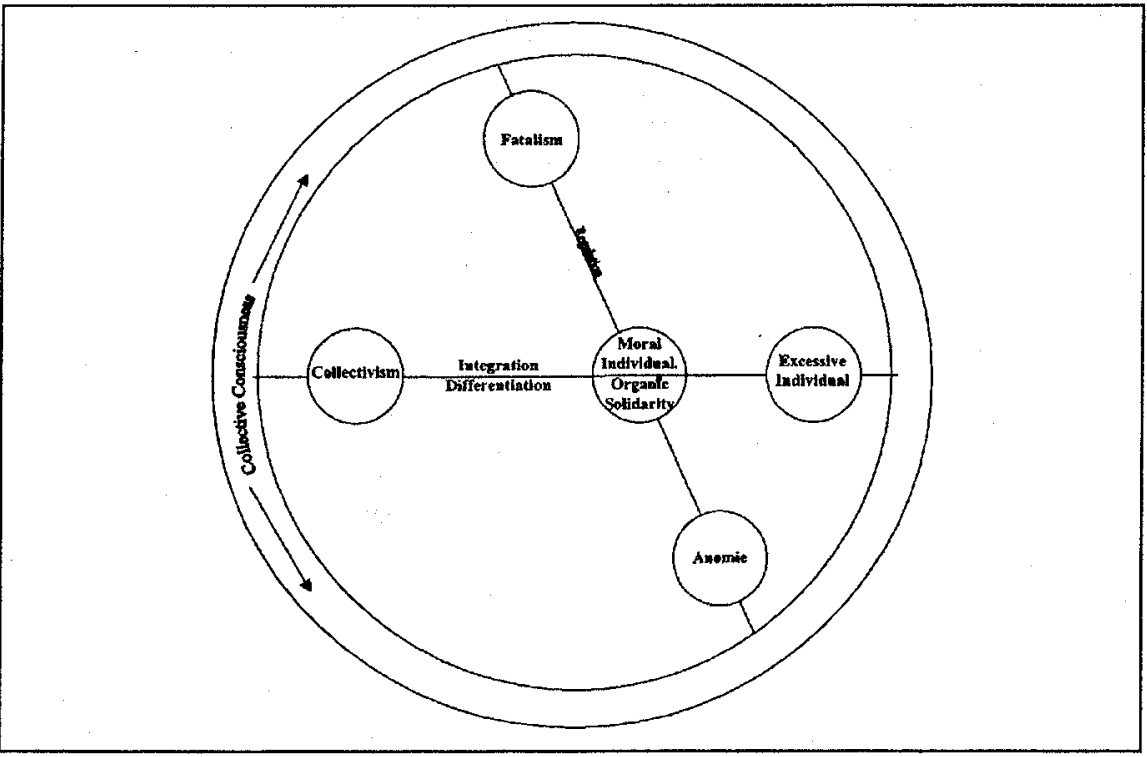

Figure 3: Durkheim's Analytical Types

The two dimensions (integration/differentiation and regulation) are analytically distinct but empirically related. Therefore, the two axes are not orthogonal to each other. Moral individualism is to be understood as an ideal-type which combines «regulation» and «integration» in an optimal way. As a theoretical perspective, moral individualism realizes that «individualism itself is a social product, like all moralities and all religions. The individual receives from society even the moral beliefs which deify him ${ }^{38}$, moral individualism is the collective sentiment presupposed in organic solidarity ${ }^{39}$. As a social practice, moral individualism is founded on sentiments of sympathy and respect for others. Egoistic individualism finds its theoretical expression in utilitarian philosophy as represented in Spencer's work. As a social practice it is the rigorous pursuit of self-interest where (in the ideal-typical case) the individual uses other individuals as mere means to his own ends, a strategy which may incur high emotional costs as Durkheim makes clear in his discussion of egoistic suicide. Just like collectivism, egoistic individualism is particularistic

37 Cf. Besnard (1993).

38 Durkheim, Individualism and the intellectuals, quoted from Marske (1987, p. 11).

39 Cf. Giddens $(1971$, p. 480). The modern version of «moral individualism» that comes closest to Durkheim's is the social philosophy of «communitarianism» as proposed by Bellah, Etzioni and others in the USA - with important differences with respect to the conception of the state. 
rather than universalistic. It is the illusionary denial of the sociability of man; it does not indicate a lack of regulation or orientation; rather, it is a delusion. Using Habermas's terminology, one might put it this way: If egoistic individualism prevails over moral individualism strategic action dominates over communicative action ${ }^{40}$.

Anomie, on the structural level, is the 'forced division of labour' which prevents the individual from fully developing his capabilities and from working according to his faculties. On the level of personality, it is the failure, due to a lack of moral regulation, of the individual to constrain and reintegrate his diverse needs and desires which are stimulated and differentiated by a rapidly growing economy. He falls prey to his unbridled needs and desires, not knowing his proper place in society, and, as one might put it today: not finding a clearly delimited personal identity. Durkheim was wavering between the idea that pathological levels of anomie would be reached only in times of rapid social change ( «acute» anomie) and the fear that the dynamics of an increasingly unregulated economy and the ensuing «moral anarchy» would render anomie chronic ${ }^{41}$. Before looking at socio-structural arrangements that may promote anomie and excessive individualism, I will briefly consider the relationship between Durkheim's types of individualism and homicide.

Durkheim has explained at some length ${ }^{42}$ why the decline of collectivism should decrease homicide. He has also carefully spelled out why anomie and egoistic individualism should be conducive to suicide. It is much less clear from his writings why pathological individualism should stimulate criminal activities including interpersonal violence. He explicitly states that those socio-structural conditions which stimulate anomic suicide are also conducive to homicide. Egoistic individualism, instead, he assumes to be a stimulant only to suicide, not to murder ${ }^{43}$. But Durkheim's argumentation appears to be inconsistent on this point. If the egoist treats his fellow human beings primarily as a means to achieving his own personal ends, why should he not be motivated to inflict harm upon the other person, or even kill him, if he stands in his way (as practiced by contract killers viz. those persons that have hired them)? Gary LaFree (referring to work done by Steffensmeier) notes that in the United States « the rate of instrumental, felony-related killings (e.g., contract murders) increases substantially during the postwar period (from about 7 percent of all murders in 1960 to about 20 percent in 1990)» ${ }^{44}$. Durkheim (at least in his suicide book) seems to overlook the possibility that murder, though it might be committed out of passion, could also be done cold-bloodedly or even out of boredom as well. Furthermore, anomie as well as egoistic individualism may stimulate forms of a defensive, reactionary collectivism as exemplified in the activities of neo-nazi groups in Germany or the revival of religious fundamentalism in the USA (using, for example, violence against medical doctors who support abortion). I would even surmise, that the practice of capital punishment, the increasing number of executions in the USA since the 1980 s also point to this «elective affinity"

\footnotetext{
40 Habermas (1981).

4] For a particularly careful study of Durkheims conception of anomie see Besnard (1993).

42 Cf. Durkheim (1992, chp. 10).

43 Durkheim (1951, pp. 358-359).

44 LaFree (1998, pp. 40-41). The promulgation of «instrumentalism» as the seedbed of barbarism within modern societies is a theme, of course, that has been prominent within various traditions of sociological and philosophical thinking (most notably, perhaps, within the Frankfurt School of social philosophy: Adorno, Horkheimer, Marcuse, Fromm).
} 
between excessive individualism and reactionary (regressive) collectivism as a specific type of «over-regulation». Due to the limitation of space I cannot pursue this issue any further here. I would rather like to take a brief look at the other side of the functional relationship with which Durkheim was concerned: What are the societal structures that foster moral individualism on the one hand or pathological forms of integration/regulation on the other hand? And do we have reason to assume that anomie, excessive individualism, and reactionary collectivism are rising?

\subsection{The Role of the State}

As for Durkheim, the most decisive role is played by the state in its relation to the economy. The state is «the organ of moral discipline ${ }^{45}$, but it is also the champion of individualism. Without the state, the individual could not have been set free from his primordial bondages, without the state there would be no power to protect the individual against the «tyrannic» claims of his group. Durkheim, by a review of history, is led to the conclusion that «except for the abnormal cases..., the stronger the state, the more the individual is respected ${ }^{46}$. Durkheim expressly rejects the hegelian, the socialist and the utilitarian (liberal) conception of the state. What he had in mind was a democratic state whose power had to be limited by strong secondary groups, free social associations, that would mediate between the individual and the state. The state, however, should be strong enough to protect moral individualism from the onslaught of moral anarchy that was looming in the economic sphere threatening to intrude into other spheres of social life. The state should have adequate regulatory power to secure sufficient measures of justice, equity and equality considered to be structural pre-conditions without which moral individualism could not be maintained ${ }^{47}$.

So, looking back at Elias's theory, we have to add a third stage in the pacifying process of state formation: The monopoly of violence and political democratization (the rule of law and the generalized right to vote) had to be supplemented by social democratization, that is, by installing some form of the welfare state. In the European nations this development progressed into the 20th century and reached its climax in the late $60 \mathrm{~s}$, early $70 \mathrm{~s}$ and has come under increasing attack since then for ideological, political and economic reasons ${ }^{48}$. This does not seem to fit neatly into the trend of homicide rates that started their upsurge earlier in the sixties. From a

45 Durkheim (1992, pp. 72, 69).

46 Durkheim (1992, p. 57).

47 Though Durkheim believed that anomie was not inherent in the advanced division of labor, he was deeply concerned about the 'crisis of (his) time'. He envisioned a situation in which anomie had become chronic and where government instead of regulating economic life would become its tool and servant ( $c f$. Marske 1987, p. 9). Durkheim certainly overstated his case by assuming that there was no social fact without a moral fact, that each aspect of social structure was infused with moral meaning ( $c f$. Fenton, 1984). But his insights into the functions the state must perform in order to maintain moral individualism and organic solidarity remain suggestive. - The problem of anomie could be re-phrased in terms of Habermas's ideas on the «systems of purposive action » encroaching upon ("colonizing») the «life-world» of human beings, in other words the social arena in which individuals engage in communicative action to built up and preserve personal and collective identities (Habermas, 1981).

48 The role of the welfare state in holding down violent crime (or limiting its increase) has been documented by several cross-national studies, among them Gartner (1990); Messner, Rosenfeld (1997); Tham (1998). 
methodological point of view, however, one has to consider the possibility that long term processes (like the restructuring of the relationship between the nation-state and the economy, the erosion of the legitimacy and effectiveness of the monopoly of violence, increasing deficits in self-control) may have taken up where short-term processes stopped. With respect to short-term forces, Gurr has suggested ${ }^{49}$ that the first wave of increased interpersonal violence in the sixties was partly the result of a post-war baby boom which increased significantly the proportion of crime-prone young men. On the other hand, the large-scale societal transformations that might undermine «organic solidarity » and «moral individualism » had been on the move for quite a while before «Thatcherism» and «Reagonomics» came in, and the advances in electronic communication and economic globalization accelerated. The students' rebellion in the mid-sixties indicated a serious generational and political legitimation crises ${ }^{50}$; «post-industrialism» led to changes not only in occupational structures, but also in life-style, gender relations and family structures; finally, the abandonment of the Bretton Woods agreement in 1971 (that is, the abolition of the system of fixed exchange rates) already signaled the growing power of unaccountable and amorphous international financial forces ${ }^{51}$.

\section{CONCLUSION}

The postwar baby-boom, the political legitimation crisis (as indicated by various protest movements starting in the early $1960 \mathrm{~s}$ ), a slackening economy (with rising inflation and unemployment since the early 1970s) - all these (and some other shortterm) forces have cumulatively contributed to starting the upward trend in violent crime since the 1960s. But as such, they could not have effected a lasting reversal of the long-term trend that had gone downward for centuries. In order to predict or account for a lasting reversal of the trend, one has to look at more fundamental processes of social change, processes that have been summarized by various authors under such labels as «post-industrialism» (Bell), «high-modernity» (Giddens), «post-modernity» (Baumann), «risk society» (Beck), « information age» (Castells) and, in recent years most often, as «globalization processes».

Elias and Durkheim, both of them, offer clearly focused analytical frameworks that (despite of some conceptual shortcomings and outdated premises ${ }^{52}$ ) help to identify among the complexly intertwined processes of social change (and the welter of social theories that seek to describe and explain them) those elements and components that might be most relevant for understanding long-term trends in violent crime. Both point to the crucial role of the state, Elias emphasizing its control over the means of violence, Durkheim its general regulatory capacity, in particular over the economy. Both portray the (democratic) state as being instrumental

\footnotetext{
49 Gurr (1989).
}

so Gary LaFree (1998) has made the loss of legitimacy of political and social institutions the key concept in has explanation of rising crime rates in the United States since the 1960s.

51 Cf. Taylor (1997, p. 286).

52 Obviously, Elias's and Durkheim's theories could easily be amended by insights from other sociological classics, in particular Max Weber and Georg Simmel; and some of the shortcomings and flawed premises could readily be corrected by contemporary research and theorizing within various fields, including psychology and history. 
in the progressive development of a culture of non-violence which, as Durkheim points out, decisively rests upon the state's capacity to insure a sufficient degree of justice and equality. Only the state has the capacity to balance personal freedom and equality. Elias and Durkheim characterize «modernization» as an ongoing process of « individualization» which both interprete as normatively desirable. Both point to discontinuities and imbalances inherent in these processes, and Durkheim envisions the possibility that moral anarchy and the powerful dynamics of the economy may eventually undermine the regulatory capacity of the state and the cooperative forms of «moral » individualism, thereby giving way to crime conducive forms of « egoistic » individualism and «anomie ».

Most economists and social scientists seem to agree upon the observation that inequality and social marginalization have generally been rising since the 1970 s and will continue to do so in the foreseeable future. At the same time, the state's monopoly of violence and of taxation has been eroding, and its general capacity to regulate economic and social affairs in such a way as to maintain moral individualism seems to be dwindling. On a very general and abstract level of thinking, one might particularly note the following long-term processes as containing the potential for chronic forms of anomie:

(1) The increasing pace of technological innovations and shortened production cycles, coupled with organizational reforms and personnel-turnover, lead to changes in our material and symbolic environments that develop faster than our capacity to make sense of them and to construe secure normative orientations towards them. The number of options from which we have to choose increases whereas the criteria on which to base our choices become uncertain. And once we have managed to seperate the desirable from the desired, we discover that the number of desirable options is much larger than the time and material resources needed to realize them. The sense of «contingency» is thus promulgating and intensifying, fostering instrumentalist orientations and making it less likely to build up value commitments that convey a firm sense of identity, orientation, and responsibility.

(2) Mankind is not only perfecting the means to manipulate (and put in danger) the natural environment, but also the internal nature of the human species. Technologies are becoming available that allow for the manipulation of our own bodies: to reshape them, to interfere with the chemistry of our brains, the reproduction of our cells, the genetic outfit that we convey to our children, and perhaps, we will eventually be able to copy our own bodies and treat them as commodities. This will drastically change the conception of our selfs and of human dignity in general. Can we still «worship» (Durkheim) the individual whose feelings and sensations can be manipulated by technical means, and whose boly can be repaired in almost all its parts? If it were the case that a large majority of all the people in the world would opt for not going any further on this road, the systemic logic of a globalized free market economy would still push forward to continue in the same direction. This might be a self-fulfilling prophecy, but it would still be anomie, worse than ever, perhaps.

Martin-Luther Universität Halle-Wittenberg Institut für Soziologie

D-06099 Halle (Saale)

thome@soziologie.uni-halle.de 


\section{BIBLIOGRAPHY}

Bell, D., The Cultural Contradictions of Capitalism, New York, Basic Books, 1976.

Besnard, P., Anomie and fatalism in Durkheim's theory of regulation, in Turner, S. P., (Ed.), Émile Durkheim, Sociologist and Moralist, London, New York, Routledge, 1993, pp. 169-190.

Castells, M., The Power of Identity, Oxford, Blackwell, 1997.

Creveld, M. van, The Rise and Decline of the State, Cambridge, Cambridge University Press, 1999.

Durkheim, É., Suicide, New York, The Free Press, 1951 (First publication: Le suicide, Paris, Félix Alcan, 1897).

Durkheim, É., Two laws of penal evolution, in Traugot, M., (Ed.), Émile Durkheim on Institutional Analysis, Chicago, The University of Chicago Press, 1978, pp. 153-180. (First publication: Deux lois de l'évolution pénale, L'Année sociologique, 1899-1900, 4, pp. 65-95).

Durkheim, É., Professional Ethics and Civic Morals, 2nd ed., London, Routledge, 1992. (First Publication: Leçons de Sociologie. Physique des mæurs et du droit, Paris, Presses Universitaires de France, 1950).

Eisner, M., Socio-economic modernization and long-term developments of crime, Theories and empirical evidences in Europe, in Council of Europe, (Ed.), Crime and Economy (Criminological Research, Vol. 32), Strasbourg, 1995, pp. 13-52.

Eisner, M., Das Ende der zivilisierten Stadt? Die Auswirkungen von Modernisierung und urbaner Krise auf Gewaltdelinquenz, Frankfurt, New York, Campus, 1997.

Eisner, M., Individuelle Gewalt und Modernisienung in Europa, 1200 - 2000, in Albrecht, G., Backes, O., Kühnel, W. (Ed.), Gewalt zwischen Mythos und Realität, Frankfurt a. M., Suhrkamp, 2001 (in print).

Elias, N., Über den Prozeß der Zivilisation, 2 vols., Frankfurt a. M., Suhrkamp, 1980.

Elias, N., The Civilizing Process, 2 vols, Oxford, 1982 (First publication: Über den Prozeß der Zivilisation, Basel, Haus zum Falken, 1939).

Elias, N., Die Gesellschaft der Individuen, Frankfurt a. M., Suhrkamp, 1991.

Fenton, S., Durkheim and Modern Sociology, Cambridge, Cambridge University Press, 1984.

Gartner, R., The victims of homicides: a temporal and cross-national comparaison, American Sociological Review, 1990, 55, pp. 92-106.

Giddens, A., Durkheim's political sociology, Sociological Review, 1971, 19, pp. 477-519.

Gottfredson, M. R., Hirschi, T., A General Theory of Crime, Stanford, Cal., Stanford University Press, 1990.

Gurr, T. R., Historical trends in violent crime: A critical review of the evidence, Crime and Justice, An Annual Review of Research, 1981, 3, pp. 295-350.

Gurr, T. R., Historical trends in violent crime: Europe and the United States, in Gurr, T. R., (Ed.), Violence in America, The History of Crime, Vol. 1, Newsbury Park, Sage, 1989, pp. 21-54.

Habermas, J., Legitimationsprobleme im Spätkapitalismus, Frankfurt a. M., Suhrkamp, 1973. Habermas, J., Theorie des kommunikativen Handelns, 2 vols., Frankfurt a. M., Suhrkamp, 1981. Honneth, A., Joas, H., Soziales Handeln und menschliche Natur. Anthropologische Grundlagen der Sozialwissenschaften, Frankfurt, New York, Campus, 1980.

Johnson, E. A., Monkkonen, E. H., Introduction, in Johnson, E. A., Monkkonen, E. H., (Eds), The Civilization of Crime. Violence in Town \& Country since the Middle Ages, Urbane, Chicago, University of nlinois Press, 1996, pp. 1-13. 
Karstedt, S., Die moralische Stärke schwacher Bindungen. Individualismus und Gewalt im Kulturvergleich, in Albrecht, G., Backes, O., Kühnel, W., (Eds), Gewalt zwischen Mythos und Realität, Frankfurt a. M., Suhrkamp, 2001 (in print).

LaFree, G., Losing Legitimacy. Street Crime and the Decline of Social Institutions in America, Boulder, Col., Westview Press, 1998.

Luhmann, N., Die Gewissensfreiheit und das Gewissen, in Luhmann, N., (Ed.), Ausdifferenzierung des Rechts, Frankfurt a. M., Suhrkamp, 1981, pp. 326-358.

Marske, C. E., Durkheim's «cult of the individual» and the moral reconstitution of society, Sociological Theory, 1987, 5, pp. 1-14.

Mayr, G. v., Statistik und Gesellschaftslehre, vol. 3 (Moralstatistik mit EinschluB der Kriminalstatistik), Tübingen, Mohr, 1917.

Messner, S. F., Societal development, social equality, and homicides. A cross-national test of a Durkheimian model, Social Forces, 1982, 61, pp. 225-239.

Messner, S. F., Rosenfeld, R., Political restraint of the market and levels of criminal homicide: A cross-national application of institutional-anomie theory, Social Forces, 1997, 75, p. 1393-1416.

Piaget, J. P., Das moralische Urteil beim Kinde, Frankfurt a. M., Suhrkamp, 1979 (French original: Le jugement moral chez l'enfant, Presses Universitaires de France, 1932).

Prinzig, F., Die eheliche Fruchtbarkeit in Deutschland, Zeitschrift für Socialwissenschaft, 1901, 4, pp. 33-38.

Spierenburg, P., Long-term trends in homicide: theoritical reflections and Dutch evidence, fifteenth to twentieth century, in Johnson, E.A., Monkkonen, E.H., (Eds.), The Civilization of Crime. Violence in Town and Country since the Middle Ages, Urbana, Chicago, University of Illinois Press, 1996, pp. 63-105.

Taylor, I., The political economy of crime, in Maguire, M., Morgan, R., Reiner, R., (Eds), The Oxford Handbook of Criminology, Oxford, Clarendon Press, 1997, pp. 265-303.

Tham, H., Crime and the welfare state: The case of the United Kingdom and Sweden, in Ruggiero, V., South, N., Taylor, I., (Eds), The New European Criminology, London, New York, Routledge, 1998, pp. 368-394.

Thome, H., Legitimitätstheorien und die Dynamik kollektiver Einstellungen, Opladen, Westdeutscher Verlag, 1981.

Thome, H., Sozialökologische Analyse der Kriminalität in Deutschland am Ende des 19. Jahrhunderts. Forschungsberichte des Instituts für Soziologie. Der Hallesche Graureiher 99-5, 1999, pp. 1-82.

Thome, H., Kriminalität im Deutschen Kaiserreich, 1883-1902, Geschichte und Gesellschaft, 2002 (in print).

Tilly, C., As Sociology Meets History, New York, Academic Press, 1981.

Trotha, T. von, Ordnungsformen der Gewalt oder Aussichten auf das Ende des staatlichen Gewaltmonopols, in Nedelmann, B., (Ed.), Politische Institutionen im Wandel (Sonderheft 35 der Kölner Zeitschrift für Soziologie und Sozialpsychologie), Opladen, Westdeutscher Verlag, 1995, pp. 129-166. 